\title{
VI. MUNICIPAL MARKETS IN PHILADELPHIA
}

\author{
By Achsar LippincotT,
}

Clerk of Markets, Philadelphia.

Municipal markets in Philadelphia are not new. In colonial days Philadelphia was distinguished for its long rows of market buildings and for the general excellence of its marketing facilities. As early as 1683 there was a city market house, and in 1736 records show that councils endenvored to get control of the ferries in order to bring the products of Jersey to the Philadelphia markets.

At that time the principal markets were on High Street, now called Market Street, in the vicinity of the Court House. In a poetic description of High Street, written in 1729, the Court House and adjoining markets are thus described:

\footnotetext{
Through the arch'd dome and on each side, the street Divided runs, remote again to meet.

Here, eastward, stand the traps for obloquy

And petty crimes-stocks, posts and pillory.

And twice a week, beyond, light stalls are set, Louded with fruits and flowers und Jersey's meat.

Westward, conjoin, the shambles grace the court,

Brick piles their long extended roof support.

Oft, west from these the country wains are seen

To crowd each hand and leave a breadth between.
}

None of these buildings is standing today.

Unfortunately Philadelphia's once well developed market system, like that in other American cities, has not kept pace with the development of modern industries. The world has progressed with discoveries of all sorts to benefit the human race and much has been done in the physical upbuilding of cities in many respects but the local marketing and distributing facilities seem to have been overlooked.

Little or no effort has been made to solve the problems of distribution in such a way as to encourage the farmers in the outlying agricultural districts to accommodate their productions to the needs of the local market nor indeed even to ship their produce to city markets. 
The efficient distribution of Philadelphia's food supply is a tremendous problem which is just beginning to receive its due attention. Director Morris I. Cooke, of the Department of Public Works, is giving the matter his serious thought. He has recently appointed a clerk of markets in the bureau of city property who has the supervision of existing markets; of the location of new curbstone and municipal markets, and who is to make inquiry into possible steam, trolley and motor boat development that will tend to expedite and cheapen the distribution of foodstuffs.

Philadelphia's most powerful agents of local distribution, namely trolley freight, good roads, motor trucks and motor boats, are to be more thoroughly developed. What is most needed is some means by which the farmers within a radius of fifty miles can get their goods to the city markets as quickly and cheaply as possible. The farmer's time is valuable and if it is necessary for him to take two or three days of every week to market his goods, can we blame him for selling to the wholesale buyer in order to save time? Just this state of affairs is what makes the city consumer pay such high prices for foodstuffs.

When Philadelphia has a waterfront terminal market and trolley freight depots at the municipal markets, then it will be possible to see the advantages of direct marketing.

The two municipal markets at North and South Second Street are financially successful. The receipts for 1913 from the five hundred stalls rented up to September first, were $\$ 17,078.25$. However the success of municipal markets must not be reckoned in terms of profit, but rather in terms of the number of bona fide farmers and consumers frequenting them.

Both farmers and professional retailers are to be found in Philadelphia's markets. Unfortunately most of the farmers frequenting the markets sell only at wholesale and have left the market before the consumer arrives there. Again the question of time enters into the matter - the farmer is not willing to take the time to retail the large quantities of his goods in the height of the seasons.

This fact emphasizes the necessity of having well organized, wholesale municipal markets. There should be a large wholesale market to which the farmer could ship his produce directly. If the farmer is assured of a steady demand and of a reliable market for his products he will raise more and be able to sell at more reasonable rates. But in selling directly to the consumer the farmer must pay 
more attention to the quality and standard of his goods. The sorting and repacking of goods are among the expensive services rendered by the middleman, which can be dispensed with. The service of a large municipal market, such as Philadelphia should have, is to eliminate unnecessary handling and to make a direct communication between the producer and the consumer, thus reducing the cost to the consumer.

In order to encourage reliable farmers to frequent the municipal markets, a concession is made to them in that they are not required to pay more than twenty dollars per year rent for stalls in the markets. If they are not bona fide farmers they must procure venders' licenses and be subject to mercantile appraisement. Further concessions should be made, and, most important of all, bulletins should be issued which would keep the producers posted on city market prices. It is the present plan to work up such a bulletin for the guidance of the farmers.

There are three phases in the logical dəvelopment of a market: first, the curbstone market; second, the open shed; and third, the modern enclosed market house. Strange as it may seem, Philadelphia's municipal markets are in the second phase-namely open sheds. The North and South Second Street markets are all that remain to us of Philadelphia's once well-developed market system. These markets were built in 1785 and 1745 respectively, and, with the exception of the addition of sheet iron roofs, cement floors and the systematizing of the numbering of the stalls, they stand as they were built. Plans are under way for the general improvement of these markets along the lines of water supply, drainage and other conveniences.

It would be practically an easy task for Philadelphia to establish new municipal markets in different sections of the city, but the vital question is, can we, in this day of the telephone and the corner grocery store, bring back the old custom of marketing? Since the corner grocer has come to stay, as he undoubtedly has in some sections of the city, it would seem that the city's next step should be to facilitate wholesale buying and distribution. Foreign cities have proved the advisability of such a system. Let Philadelphia be the first American city to adopt the improved market system, and to develop to the fullest extent the powerful agencies of local distribution at its immediate disposal. 